\title{
PENGEMBANGAN LKPD BERBASIS KETERAMPILAN PROSES SAINS DALAM MODEL PEMBELAJARAN INKUIRI TERBIMBING: STRUKTUR DAN FUNGSI JARINGAN TUMBUHAN
}

\section{THE DEVELOPMENT OF STUDENT WORKSHEET BASED ON SCIENCE PROCESS SKILS IN GUIDED INQUIRY LEARNING MODEL: STRUCTURE AND FUNCTION OF PLANT NETWORKS}

\author{
Baiq Fitri Raudatul Hikmah, I Putu Artayasa*, dan Dewa Ayu Citra Rasmi \\ Program Studi Pendidikan Biologi FKIP, Universitas Mataram, Mataram, Indonesia \\ *Email: artayasa75@unram.ac.id
}

Diterima: 3 Maret 2021. Disetujui: 18 Mei 2021. Dipublikasikan: 2 Juni 2021

\begin{abstract}
Abstrak: Penelitian ini bertujuan untuk (1) menghasilkan perangkat pembelajaran berupa Lembar kerja Peserta Didik (LKPD) berbasis keterampilan proses sains dalam model inkuiri terbimbing materi struktur dan fungsi jaringan tumbuhan yang layak diterapkan sebagai perangkat pembelajaran tambahan berdasarkan penilaian validator (2) Menghasilkan LKPD berbasis keterampilan proses sains dalam model inkuiri terbimbing pada materi struktur dan fungsi jaringan tumbuhan yang dapat diterapkan sebagai perangkat pembelajaran tambahan berdasarkan tanggapan peserta didik Penelitian ini dilakukan di SMPN 3 Mataram dan SMPN 7 Mataram. Prosedur pengembangan perangkat mengikuti model pengembangan 4-D yang terdiri dari define, design, develop, dan disseminate. Tehnik pngumpulan data dilakukan meggunakan angket untuk penilaian ahli dan respon peserta didik. Hasil penelitian ahli menunjukkan Skor penilaian terhadap LKPD sebesar $81,48 \%$ dan termasuk dalam kriteria sangat layak. Uji coba terbatas LKPD pada peserta didik kelas VIII menunjukkan skor $77,37 \%$ dan termasuk dalam kategori dapat diterapkan.
\end{abstract}

Kata Kunci: LKPD, Keterampilan proses sains, inkuiri terbimbing

Abstract: Firstly, this study aims to produce learning tools in Student Worksheets based on science process skills in a guided inquiry model. The structure and function of plant networks appropriate to be applied as additional learning tools based on validator assessments. Secondly, to produce LKPD based on process skills science in the guided inquiry model on the material structure and function of plant tissue that can be applied as an additional learning tool based on students' responses. The research was conducted at SMPN 3 Mataram and SMPN 7 Mataram. The device development procedure follows the 4-D development model, which consists of defining, designing, developing, and disseminating. Data collection techniques were carried out using questionnaires for expert judgment and student responses. The results of expert research showed that the assessment score of LKPD was $81.48 \%$ and was included in the very feasible criteria. The Student Worksheets limited trial on class VIII students showed a score of $77.37 \%$ and was included in the appropriate category.

Keywords: LKPD, science process skills, guided inquiri

\section{PENDAHULUAN}

Pendidikan merupakan salah satu unsur penting dalam mewujudkan sumber daya manusia yang berkualitas. Pendidikan yang berkualitas sangat dibutuhkan oleh suatu negara untuk terus menjaga eksistensinya. Dengan demikian, untuk mewujudkan suatu sistem pendidikan yang berkualitas perlu untuk membekali peserta didik dengan keterampilan dalam proses pembelajaran agar mudah memahami dengan cepat materi-materi yang diajarkan oleh guru. Misalnya dalam pembelajaran IPA guru perlu mengembangkan keterampilan proses sains kepada peserta didik [1]. Hikmah mengungkapkan keterampilan proses sains dalam pembelajaran IPA merupakan pengetahuan dasar tentang konsep-konsep dalam yang diperoleh oleh peserta didik dalam memahami konsep dasar dalam pembelajaran IPA [2].

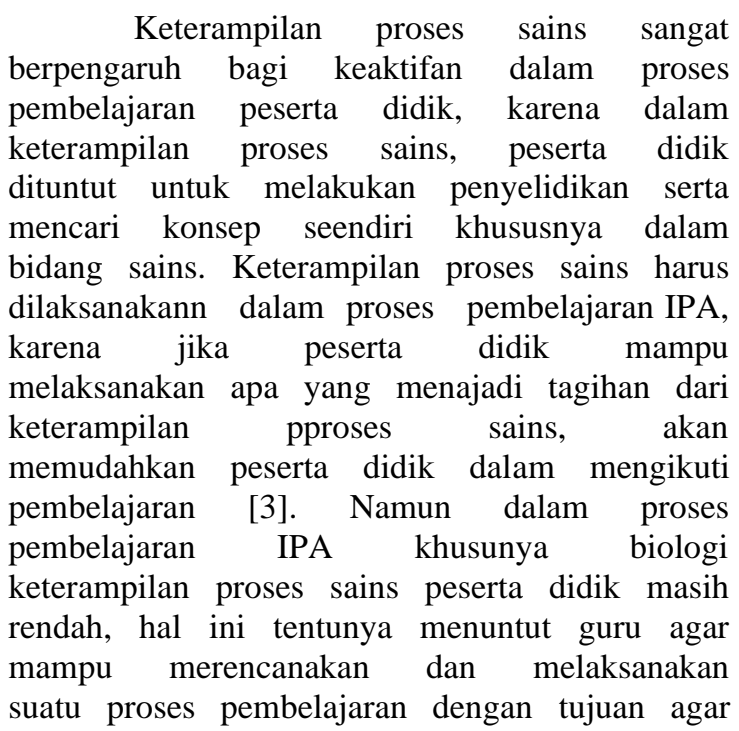


keterampilan proses sains peserta didik menimgkat [4].

Berdasarkan hasil penelitian yang dilakukan oleh Damopoli [5] bahwa Pemberdayaan keterampilan proses sains perlu dilakukan, karena peserta didik yang telah menguasai indikator keterampilan proses sains akan lebih mudah mempelajari IPA khususnnya biologi dengan pengalamannya sendiri. Namun kenyataan yang terjadi disekolah - sekolah bahwa keterampilan proses sains belum terberdayakan sehingga nilai keterampilan proses sains yang masih rendah. Pembelajaran sains yang masih sekedar mentransfer ilmu pengetahuan dan berpusat pada guru, mengakibatkan tidak berkembangnya gagasan serta tidak diperolehnya pengalaman untuk memahami konsep secara utuh Masih lemahnya Keterampilan Proses Sains (KPS) diperkuat hasil penelitian Anam [6] yang melakukan penelitian terhadap tiga puluh (30) peserta didik perwakilan dari 30 MI di Kabupaten Sumedang pada kegiatan Kompetensi Sains Madrasah (KSM). Hasil penelitian menunjukkan bahwa keterampilan proses sains peserta didik masih rendah dilihat dari jenis kegiatan yang dilakukan berupa pengamatan, pengklasifikasian dan membuat kesimpulan peserta didik masih kurang mampu. Demikian juga hasil penelitian Sukarno,dkk [7] yang menjelaskan bahwa keterampilan proses sains peserta didik SMP di Jambi pada keterampilan membuat kesimpulan, mengobservasi, memprediksi, mengukur dan mengklasifikasi masih rendah. Berdasarkan beberapa hasil penelitian diatas mengenai rendahnya keterempilan proses sians peserta didik, maka perlu dilakukan penelitian yang bertujuan untuk meningkatkan keterampilan proses sains peserta didik salah satunya adalah dengan menggunakan LKPD yang disusun berdasarkan sintaks dari model pembelajaran inkuiri terbimbing [8].

Salah satu LKPD yang digunakan guru di kelas khususnya pada materi sruktur dan fungsi jaringan tumbuhan adalah LKPD konvensional. LKPD konvensional yang hanya berisi judul materi, ringkasan materi, soal-soal latihandan dan penggunaannya tergantung dengan bahan ajar lain, sehingga tidak terlihat indikator kegiatan ilmiah seperti yang tercantum pada LKPD berbasis keterampilan proses sains [9]. LKPD yang sering digunakan tersebut tidak menampilkan kegiatan penyelidikan yang akan dilakukan oleh peserta didik melainkan langsung menyampaikan permasalahan. Materi struktur dan fungsi jaringan tumbuhan tidak dapat dipelajari dengan mendengarkan penjelasan dari guru saja melainkan peserta diidk harus aktif dan mandiri. Peserta didik harus mengetahui apa yang berkaitan dengan materi dengan cara yaitu salah satunya adalah meihat langsung gambar yang terdapat dalam materi tersebut mengidentifikasi bagian apa saja yang terdapat dalam gambar, dan terjun langsung kelapangan sehingga perlu adanya perbaikan terhadap LKPD yang mneggunakan model pembelajaran dengan menerapkan model yang menyebabkan peserta didik aktif melakukan penyelidikan, model pembelajaran yang dapat meningkatkan keterampilan proses sains salah satunya yaitu model inkuiri terbimbing [10].

Penggunaan medel inkuiri terbimbing perlu digunakan dalam pengembangan LKPD karena dengan adanya pendekatan ini peserta didik dapat belajar secara aktif dengan bantuan alat, bahan serta pertanyaan yang telah disiapkan dan jawaban tersebut dapat ditemukan peserta didik melalui proses penyelidikan [11].

Mengingat pentingnya perangkat pembelajaran yaitu berupa Lembar Kerja Peserta Didik. Hal inilah yang mendorong peneliti untuk melakukan penelitian dengan menggunakan judul" Pengembangan LKPD Berbasis Keterampilan Proses Sains Dalam Model Pembelajaran Inkuiri Terbimbing Materi Struktur Dan Fungsi Jaringan Tumbuhan SMP".

Berdasarkan uraian diatas maka tujuan dari peneitian ini ada dua yaitu (1) Menghasilkan perangkat pembelajaran berupa LKPD berbasis keterampilan proses sains dalam model inkuiri terbimbing pada materi struktur dan fungsi tumbuhan di SMP yang layak digunakan sebagai perangkat pembelajaran tambahan (2) Menghasilkan LKPD berbasis keterampilan proses sains dalam model inkuiri terbimbing pada materi struktur dan fungsi jaringan tumbuhan SMP yang dapat diterapkan sebagai perangkat pembelajaran tambahan.

\section{METODE PENELITIAN}

Ditinjau dari objeknya, penelitian ini menggunakan jenis penelitian Research and Development $(R \& D)$ yaitu merupakan metode penelitian yang digunakan untuk mengembangkan suatu produk atau rangkaian proses untuk menyempurnakan produk yang telah ada, sesuai dengan namanya Research \& Development, semua data dan informasi yang dibutuhkan peneliti didapatkan dengan reserch sedangkan development dilakukan untuk menghasilkan atau mengembangkan perangkat pembelajaran [12-13]. Model yang digunakan dalam penelitian ini adalah model 4-D. Model ini terdiri dari 4 tahapan pengembangan yaitu Define (pendefinisian), desing 
(perancangan), develop (pengembangan), dan Desseminate (penyebaran).

Penelitian ini dilaksanakan di SMPN 3Mataram dan SMPN 7 Mataram kelas VIII semester I Tahun ajaran 2020/2021. instrumen yang digunakan dalam penelitian ini berupa lembar validasi, angket tanggapan peserta didik, RPP, LKPD. Adapun teknik analisis data yang dilakukan adalah Kelayakan (Analisis data penilaian pakar) yang terdiri dari 1 ahli yaitu dosen pendidikan biologi UNRAM dan 2 praktisi yaitu guru IPA kelas VIII di SMPN 3 Mataram dan SMPN 7 Mataram.. Adapun rumus serta kriteria atau kategori kelayakan menurut Akbar, 2013 seperti diuraikan di bawah ini.

$$
N P \cdot \frac{R}{S M} X 100 \%
$$

Keterangan:

NP :Nilai Presen yang di cari

F: skor yang diperoleh

SM : skor maksimal

Kemudian menghitung rata-rata nilai validitas dari ketiga validator dengan rumus

$$
N A \cdot \frac{N P 1 \cdot N P 2 \cdot N P 3}{3}
$$

Keterangan

NA: Nilai rata-rata

NP1: Nilai validitas pakar 1

NP2: Nilai validitas pakar 2

NP3: Nilai validitas pakar 3

Nilai tersebut kemudian dikonversikan dengan kriteria penilaian sebagai berikut:

Tabel 1 Kategori/ Kriteria Analisis Penilaian Pakar

\begin{tabular}{cc}
\hline Interval & Kriteria \\
\hline $81 \% \leq \mathrm{NP}<100 \%$ & Sangat layak \\
\hline $62 \% \leq \mathrm{NP}<81 \%$ & Layak \\
\hline $43 \% \leq \mathrm{NP}<62 \%$ & Cukup layak \\
\hline $33 \% \leq \mathrm{NP}<43 \%$ & Kurang layak \\
\hline $\mathrm{NP}<33 \%$ & Tidak layak \\
\hline
\end{tabular}

Adapun teknik analisis data yang dilakukan adalah tanggapan peserta didik terhadap LKPD. Rumus serta kriteria atau kategori kelayakan menurut Akbar, 2013 seperti diuraikan di bawah ini [14].

$$
P \cdot \frac{f}{N} X 100 \%
$$

Keterangan:

$\mathrm{P}$ : Presentase penilaian

$f$ : skor yang diperoleh

$\mathrm{N}$ : skor maksimal
Kemudian menghitung rata-rata nilai tanggapan dari kelima peserta didik dengan rumus:

NA . P1.P2.P3.P4.P5.P6.P7.P8.P9.P10

$$
10
$$

Keterangan:

NA : Rata-rata nilai

P1 : Nilai tanggapan peserta didik 1

P2 : Nilai tanggapan peserta didik 2

P3 : Nilai tanggapan peserta didik 3

P4 : Nilai tanggapan peserta didik 4

P5 : Nilai tanggapan peserta didik 5

P6 : Nilai tanggapan peserta didik 6

P7 : Nilai tanggapan peserta didik 7

P8 : Nilai tanggapan peserta didik 8

P9 : Nilai tanggapan peserta didik 9

P10: Nilai tanggapan peserta didik10

Setelah rata-rata tanggapan peserta didik dihitung, kemudian ditentukan kategori tanggapan peserta didik dengan parameter pada tabel 2 .

Tabel 2. Parameter kategori tanggapan peserta didik

\begin{tabular}{cc}
\hline Interval & kriteria \\
\hline $81 \%-100 \%$ & Sangat dapat diterapkan \\
\hline $61 \%-80 \%$ & Dapat diterapkan \\
\hline $41 \%-60 \%$ & Cukup dapat diterapkan \\
\hline $21 \%-40$ & Kurang dapat diterapkan \\
\hline$<21 \%$ & Tidak dapat diterapkan \\
\hline
\end{tabular}

\section{HASIL DAN PEMBAHASAN}

Penelitian dengan judul pengembangan Lembar Kerja Peserta Didik (LKPD) berbasis keterampilan proses sains dalam model pembelajaran inkuiri terbimbing pada materi struktur dan fungsi jaringan tumbuhan di SMP telah dilakukan. Adapun model pengembangan yang digunakan dalam penelitian ini adalah 4D yang terdiri dari (1) Define (pendefinisian) (2) design (Perancangan) (3) develop (pengembangan) dan (4) Disseminate (penyebaran). Tahap pertama adalah tahap define atau pedefinisan. Tahap difine merupakan tahap untuk menetapkan dan mendefinisikan syarat-syarat yang dibutuhkan dalam pengembangan pembelajaran. Adapun langkah-langkah dalam tahap difine terdiri dari langkah (1) analisis awal, Langkah (2) analisis peserta didik. Selanjutnya langkah (3) analisis tugas. Langkah (4) Analisis konsep, Langkah (5) Perumusan tujuan pembelajaran

Tahap kedua yaitu tahap design (Perancangan) yang menggunakan Empat langkah yang dilakukan pada tahap ini, yaitu: langkah (1) penyusunan instrumen (instrument construction), Penyusunan instrumen merupakan langkah untuk menyusun instrumen dan penilaian produk. Instrument yang disusun meliputi instrumen penilaian hasil uji coba produk dengan 
menggunakan instrumen validasi LKPD dan RPP yang dilakukan oleh 3 ahli dan angket tanggapan peserta didik terhadap LKPD yang telah dikembangkan. Langkah (2) pemilihan media (media selection) yang sesuai dengan karakteristik materi dan tujuan pembelajaran, Pemilihan media dilakukan untuk mengidentifikasi media pembelajaran yang relevan dengan karakteristik materi. Pemilihan media ini disesuaikan dengan analisis awal, analisis peserta didik, analisis tugas, analisis konsep, dan perumusan tujuan. Media yang digunakan dalam penelitian ini adalah LKPD inkuiri terbimbing dan lingkungan seklilingnya. Langkah (3) pemilihan format (format selection), yakni mengkaji format- format bahan ajar yang ada dan menetapkan format bahan ajar yang akan dikembangkan, format dari LKPD meliputi judul yaitu LKPD berbasis keterampilan proses sains dalam model pembelajarn inkuiri terbimbing materi struktur dan fungsi jaringan tumbuhan di SMP, petunjuk belajar, kompetensi yang akan dicapai, langkah/kegiatan peserta didik sesuai dengan langkah inkuiri terbimbing, dan penilaian. Langkah (4) membuat rancangan awal (initial design) sesuai format yang dipilih. Rancangan awal yang dimaksud adalah rancangan seluruh perangkat pembelajaran yang harus dikerjakan sebelum uji coba dilaksanakan. Dalam tahap perancangan, peneliti sudah membuat produk awal (prototype) atau rancangan produk. Pada konteks pengembangan LKPD, tahap ini dilakukan untuk membuat LKPD dengan kerangka yang sesuai dengan model pembelajaran inkuiri terbmbing.

Tahap ketiga yaitu Tahap Develop (Pengembangan), Tahap pengembangan adalah tahap yang bertujuan untuk menghasilkan bentuk akhir perangkat pembelajaran setelah melalui revisi berdasarkan masukan para pakar ahli/ praktisi dan data hasil uji coba lapangan Langkah-langkah yang dilakukan pada tahap pengembangan bahan ajar adalah (1) Penilaian kelayakan produk LKPD yang menggunakan Validasi kepada ahli/ pakar. (2) Berdasarkan masukan para validator selanjutnya produk direvisi untuk membuat produk lebih efektif, praktis dan mudah digunakan sehingga mempunyai kualitas yang baik.

Lembar Kerja Peserta Didik (LKPD) yang baik merupakan LKPD yang memenuhi tagihan baik itu tagihan keterampilan proses sains maupun keterempilan lainnya. LKPD yang dikembangkan dalam penelitia ini merupakan keterempilan yang menuntun peserta diidk untuk melakukan penyedikan, menemukann konsep dan sebgainya, keterampilan untuk melakukan penyelidikan bertujuan agar peserta didik teresebut bisa mendapatkan jawaban sendiri dari pertanyaan yang ada di LKPD. Peserta didik yang mampu melakukan penyelidikan dan menemukan konsep sendiri baik itu melalui pengamatan menunjukkan bahwa keterempilan proses sains peserta didik tinggi, karena dalam Konteks keterampilan proses sains peserta didik dituntut untuk melakukan penyelidikan serta mampu menemukan konsep sendiri. untuk meningkatkan keterampilan proses sains peserta diidk yang rendah, peneliti mengembangkan LKPD model inkuiri terbimbing agar peserta didik dapat melakukan pengamatan langsung baik itu dalam bentuk identifikasi gambar, maupun terjun langsung ke lapangan.

\begin{tabular}{lccr}
\multicolumn{2}{c}{ Karakteristik } & LKPD & berbasis \\
keterampilan & proses & $\begin{array}{r}\text { dengan } \\
\text { model }\end{array}$ \\
pembelajaran & inkuiri & terbimbing & meliputi \\
tahapan & mengidentifikasi & masalah, \\
merumuskan & masalah, & membuat & hipotesis, \\
mengumpulkan & data, & dan & membuat \\
kesimpulan & Berikut & ini & merupakan
\end{tabular}
karakteristik yang dimiliki oleh LKPD pada materi struktur dan fungsi jaringan tumbuhan yang dikembangkan dalam penelitian ini

\section{Cover (sampul)}

Berisi nama produk yaitu Lembar Kerja Peserta Didik (LKPD) berbasis keterampilan proses sains dalam model inkuiri terbimbing materi struktur dan fungsi jaringan tumbuhan kelas VIII SMP. Dirangkaikan dengan nama peneliti serta nama doses pembimbing.

Isi

Berisi bahan ajar yang terdiri dari judul, kelas, dan semseter dirangkaikan dengan nama peneliti, Kompetensi Inti, Kompetensi Dasar bserta indikator, ringkasan materi dan yang terakhir yaitu Lembar Kerja Peserta Didik (LKPD).

\section{Gambar}

Gambar yang digunakan yaitu gambar ilustrasi tentang tumbuhan. LKPD 1 dengn tema struktur akar tumbuhan menampilkan gambar berbagai jenis akar, gambar struktur melintang ( anatomi) akar. LKPD 2 dengn tema struktur batang tumbuhan menampilkan gambar berbagai jenis struktur melintang ( anatomi) batang. LKPD 3 dengn tema struktur daun tumbuhan menampilkan gambar berbagai jenis daun, gambar struktur melintang (anatomi) daun. Dan yang terakhir adalah LKPD 4 dengn tema struktur bunga tumbuhan menampilkan gambar berbagai jenis bunga, gambar struktur melintang ( anatomi) bunga.

\section{Uji Kelayakan LKPD}

LKPD berbasis keterampilan proses sains dalam moel inkuiri termbimbing yang telah dikembangkan divalidasi oleh 3 validator dan berdasarkan penilian ketiga validator tersebut 
bahwa LKPD yang dekembangkan termasuk kategori sangat layak dengan skor rata-rata $81,48 \%$. Data hasil penilaian kelayakan LKPD pada tahap validasi disajikan pada tabel 4.1 berikut ini.

Penilaian kelayakan LKPD dilihat dari data hasil validasi berdasarkan tabel 4.1 Hasil validasi pertama yang dilakukan oleh Dosen Pendidikan Biologi Unram yaitu Drs. Lalu Japa, M.Sc.St. menunjukkan bahwa jumlah nilainya keseluruhan adalah 36 dengan Perolehan nilai persentase seluruh aspek adalah $80 \%$ dengan kategori layak.

Tabel 3 Data skor penilaian uji kelayakanLKPD

\begin{tabular}{|c|c|c|c|c|}
\hline $\begin{array}{c}\text { Aspek } \\
\text { penilaian }\end{array}$ & NP1 & NP2 & NP3 & $\begin{array}{c}\text { Skor } \\
\text { maksimal }\end{array}$ \\
\hline kelayakan & 12 & 12 & 13 & 15 \\
\hline $\begin{array}{l}\text { Penyajian/ } \\
\text { format }\end{array}$ & 12 & 14 & 11 & 15 \\
\hline $\begin{array}{l}\text { Kelayakan } \\
\text { isi }\end{array}$ & 12 & 14 & 11 & 15 \\
\hline $\begin{array}{l}\text { Kelayakan } \\
\text { bahasa }\end{array}$ & 12 & 12 & 12 & 15 \\
\hline Jumlah & 36 & 38 & 36 & 45 \\
\hline NP & $80 \%$ & $84,44 \%$ & $80 \%$ & $100 \%$ \\
\hline NA & \multicolumn{4}{|c|}{$81,48 \%$} \\
\hline Kategori & \multicolumn{4}{|c|}{ Sangat layak } \\
\hline \multicolumn{5}{|c|}{$\begin{array}{l}\text { Keterangan : } \\
\text { NP1= Nilai persentase validator } 1 \\
\text { NP2 = Nilai persentase validator } 2 \\
\text { NP3=Nilai persentase validator } 3\end{array}$} \\
\hline $\begin{array}{l}\text { Ha } \\
\text { oleh guru } \\
\text { Fitran Sa } \\
\text { jumlah ni } \\
\text { perolehan } \\
\text { adalah } 84 \\
\text { Ketiga ada } \\
\text { guru IPA } \\
\text { menunjukk }\end{array}$ & $\begin{array}{l}\text { il val } \\
\text { IPA } \\
\text { i, } \\
\text { i kes } \\
\text { nilai } \\
\% \text { de } \\
\text { he hasi } \\
\text { MP } 7 \\
\text { n bah }\end{array}$ & $\begin{array}{l}\text { dasi ked } \\
\text { MP } 3 \text { I } \\
\text { Pd. me } \\
\text { luruhan } \\
\text { persentas } \\
\text { gan kate } \\
\text { validasi } \\
\text { Mataram } \\
\text { va juml }\end{array}$ & $\begin{array}{l}\text { la yan } \\
\text { Mataram } \\
\text { nunjukk } \\
\text { adalah } \\
\text { e selt } \\
\text { gori sc } \\
\text { yang di } \\
\text { yaitu } \mathrm{R} \\
\text { a nila }\end{array}$ & $\begin{array}{l}\text { dilakukan } \\
\text { yaitu Dra } \\
\text { an bahwa } \\
38 \text { dengan } \\
\text { Iruh aspek } \\
\text { ingat layak. } \\
\text { lakukan oleh } \\
\text { aihani, S.Pd. } \\
\text { keseluruhan }\end{array}$ \\
\hline
\end{tabular}

adalah 36 dengan perolehan nilai persentase seluruh aspek adalah $80 \%$ dengan kategori layak. Setelah dilakukan penginputan nilai berdasarkan rumus maka diperoleh nilai rata-rata persentase dari ketiga validator yaitu $81,48 \%$ dengan kategori sangat layak.

\section{Hasil Uji Coba Lapangan Terbatas}

Tanggapan peserta didik terhadap LKPD yang dikembangkan menggunakan angket tanggapan peserta didik. Jumlah peserta didik yang menjadi sampel adalah 5 orang dari SMP 3 Mataram dan 5 orang dari SMP 7 Mataram. Data hasil penilaian taggapan peserta didik terhadap LKPD yang dikembangkan, disajikan pada tabel 4.

Data hasil tanggapan peserta didik seperti disajikan pada tabel 4 menunjukkan bahwa, untuk nilai tanggapan peserta didik 1 dari nilai keseluruhan aspek adalah 65 dengan persentase $81,25 \%$, jumlah nilai tanggapan peserta didik 2 dari keseluruhan aspek adalah 64 dengan perentase $80 \%$, jumlah nilai tanggapan peserta didik 3 dari keseluruhan aspekadalah 56 dengan persentase $70 \%$, jumlah nilai tanggapan peserta didik 4 dari keseluruhan aspek adalah 61 dengan perentase $76,25 \%$, dan jumlah nilai tanggapan peserta didik 5 dari keseluruhan aspek adalah dengan persentase $76,25 \%$, dan jumlah nilai tanggapan peserta didik 5 dari keseluruhan aspek adalah dengan persentase 77,5\%. Jumlai nilai 6 dari keseluruhan aspek adalah 63 dengan persentase $78,75 \%$. Jumlah nilai tanggapan peserta didik 7 dari keseluruhan aspek adalah 59 dengan perentase $73,75 \%$. Jumlah nilai tanggapan peserta didik 8 dari keseluruhan aspek adalah 62 dengan perentase 77,5\%. Jumlah nilai tanggapan peserta didik 9 dari keseluruhan aspek adalah 61 dengan perentase $76,25 \%$ dan terkahir jumlah nilai tanggapan peserta didik 10 dari keseluruhan aspek adalah 66 dengan perentase $82,5 \%$.

Tabel 4 Data Skor Tanggapan Peserta Didik terhadap LKPD

\begin{tabular}{|c|c|c|c|c|c|c|c|c|c|c|c|}
\hline $\begin{array}{c}\text { Aspek } \\
\text { penilaian }\end{array}$ & P1 & $\mathrm{P} 2$ & P3 & $\mathrm{P} 4$ & P5 & P6 & $\mathrm{P7}$ & P8 & P9 & P10 & Aspek yang dinilai \\
\hline Kebahasaan & 4 & 3 & 3 & 3 & 4 & 4 & 3 & 3 & 3 & 4 & 4 \\
\hline Isi & 36 & 38 & 30 & 36 & 31 & 35 & 27 & 30 & 30 & 34 & 44 \\
\hline Penyajian & 25 & 23 & 23 & 22 & 27 & 24 & 29 & 29 & 28 & 28 & 32 \\
\hline Jumlah & 65 & 64 & 56 & 61 & 62 & 63 & 59 & 62 & 61 & 66 & 80 \\
\hline $\mathrm{P}(\%)$ & 81,2 & 80 & 70 & 76,2 & 77,5 & 78,7 & 73,7 & 77,5 & 76,2 & 82,5 & 100 \\
\hline NA $(\%)$ & \multirow{2}{*}{\multicolumn{11}{|c|}{$\begin{array}{l}77.37 \\
\text { t diterankan }\end{array}$}} \\
\hline Kriteria & & & & & & & & & & & \\
\hline
\end{tabular}


Keterangan:

P1 : Nilai persentase tanggapan PD 1

P2 : Nilai persentase tanggapan PD 2

P3 : Nilai persentase tanggapan PD 3

P4 : Nilai persentase tanggapan PD 4

P5 : Nilai persentase tanggapan PD 5

P6: Nilai persentase tanggapan PD 6

P7: Nilai persentase tanggapan PD 7

P8: Nilai persentase tanggapan PD 8

P9: Nilai persentase tanggapan PD 9

P10: Nilai persentase tanggapan PD 10

Setelah nilai persentase dari kesepuluh peserta didik didapatkan lalu dihitung nilai akhir dari tanggapan peserta didik. Jumlah nilai ratarata atau nilai akhir tanggapan peserta didik menunjukkan skor $77,37 \%$ yang termasuk dalam kategori dapat diterapkan.

Pengembangan LKPD ini dilakukan penilaian berdasarkan validasi pakar serta tanggapan peserta didik terhadap LKPD. Produk LKPD berbasis keterampilan proses sains dalam model inkuiri terbimbing pada struktur dan fungsi jaringan tumbuhan dikategorikan sangat layak dengan rata-rata persentase skor penilaian validator yaitu $81,48 \%$. LKPD yang telah dikembangkan dikategorikan sangat layak karena validator memberikan penilaian tinggi pada kesesuaian LKPD dengan indikator yang akan dicapai, bahasa yang digunakan singkat, jelas, dan tidak menimbulkan pengertian ganda, kesederhanaan bahasa yang digunakan serta kesesuaian bahasa dengan taraf berpikir siswa [15-16]. Kelengkapan struktur LKPD (judul, petunjuk belajar, kompetensi yang ingin dicapai, informasi pendukung (ilustrasi dan gambar), langkah mengerjakan soal, dan tempat kosong untuk menuliskan jawaban), kejelasan format penulisan LKPD (jenis huruf, ukuran huruf, sistem penomoran) dan daya tarik atas penampilan LKPD (layout, gambar, tabel, diagram, grafik). Akan tetapi ada pula penilaian cukup yaitu kesesuaian tugas dengan pembelajaran pendekatan inkuiri terbimbing , hal ini dikarenakan antara tugas dengan pendekatan inkuiri terbimbing cukup sesuai, dikarenakan pada RPP dilakukan percobaan dan diskusi sedangkan di LKPD hanya percobaan saja oleh karena itu terdapat saran agar pendekatan inkuiri terbimbing harus sesuai dengan tugas.

Produk LKPD berbasis keterampilan proses sains dalam model inkuiri terbimbing pada struktur dan fungsi jaringan tumbuhan dikategorikan dapat diterapkan dengan rata- rata persentase skor peserta didik yaitu 77,37\%. Peserta didik memberikan penilaian tinggi yaitu pada LKPD yang telah dikembangkan menggunakan bahasa yang mudah dimengerti, gaya penyajian LKPD sangat menarik, peserta didik cepat memahami materi dengan menggunakan LKPD inkuiri terbimbing, LKPD dapat menunjang proses pembelajaran, LKPD sesuai dengan materi, kelengkapan LKPD, dan dengan menggunakan LKPD ini, peserta didik menjadi lebih akif dan kreatif.

Peserta didik memberikan nilai rendah yaitu pada materi struktur dan fungsi jaringan tumbuhan tersebut tidak sulit, ada beberapa peserta didik yang memberikan responnya yaitu LKPD pada materi struktur dan fungsi jaringan tumbuhan kurang menarik. Namun demikian, peserta didik berpendapat bahwa mereka setuju dengan LKPD yang telah di kembangkan tersebut layak diterapkan pada pembelajaran IPA karena LKPD tersebut dapat menunjang keterampilan proses sains, membuat peserta didik menjadi lebih aktif dan dapat membantu memahami dalam materi struktur dan fungsi jaringan tumbuhan.

Selain itu, dalam penelitian ini dilakukan salah satu uji yaitu uji U Mann Whitney yang dimana uji ini merupakan uji non parametris yang digunakan untuk mengetahui perbedaan median 2 kelompok bebas apabila skala data variabel terikatnya adalah ordinal atau interval tetapi tidak beristribusi normal. Terdapat 2 kelompok yaitu kelompok 1 terdiri dari 2 peserta didik dan kelompok 2 terdiri dari 8 peserta didik, akan tetapi data yang telah didapatkan menunjukkan ada 2 peserta didik yang nilainya masuk kedalam kategori sangat dapat diterapkan sedangkan 8 lainnya menunjukkan kategori dapat diterapkan. Karena adanya perbedaan kategori, maka data ini diuji lagi menggunakan Uji U Mann Whitney. Data hasil tanggapan peserta didik yang menggunakan Uji U Mann Whitney menunjukkan Nilai statistik mann whitney yaitu 0,03 uji ini dilakukan agar mengetahui apakah terdapat perbedaan yang signifikan antara tanggapan peserta didik kelompok 1 dan kelompok 2 dengan menggunakan taraf signifikan $5 \%$. Dilihat dari hasil perhitungan yang di dapatkan, bahwa nilai statistik Man-Whitney lebih kecil daripada nilai kritis Mann-Whitney (Jika nilai asymp. Sig < 0,05, maka ada perbedaan) [17]. Oleh karena itu, dapat dikatakan bahwa ada perbedaan antara kelompok 1 dan kelompok 2 pada 
tingkat signifikan 5\% yang dimana dalam hal ini berarti ada perbedaan tanggapan.

LKPD berbasis keterampilan proses sains dalam model inkuiri terbimbing pada materi stuktur dan fungsi jaringan tumbuhan yang dikembangkan sebelum diujicobakan harus dinyatakan layak terlebih dahulu, oleh sebab itu produk yang dikembangkan harus melalui tahap revisi terlebih dahulu. Revisi bertujuan untuk memperbaiki dan menyempurnakan produk yang dikembangkan sesuai dengan saran yang diberikan oleh para ahli atau validator. Beberapa saran perbaikan yang diberikan oleh validator pada aspek bahasan adalah mengenai kesalahan pengetikan, kurang konsisten dalam penomoran kalimat yang kurang efektif, dan materi yang masih kurang lengkap. Perbaikan kemudian dilakukan berdasarkan saran-saran yang telah diberikan. Perbaikan yang dilakukan pada tahap ini adalah memperbaiki kesalahan pengetikan pada bagian yang telah ditandai, mengganti beberapa kalimat yang kurang efektif menjadi kalimat yang lebih efektif. Penambahan penjelasan dari materi seperti gambar pendukung agar lebih jelas serta penomoran yang masih tidak konsisten.

Perbaikan yang dilakukan pada aspek isi adalah mengganti KD yang digunakan menjadi KD yang terbaru yang sebelumnya menggunakan KD 3.3 Mengidentifikasi struktur dan fungsi jaringan tumbuhan, dan 4.3 menyajjikan data hasil pengamatan anatomi jaringan tumbuhan untuk menunjukkan keterkaitan dengan letak dan fungsinya dalam biproses . Pergantian dilakukan dengan saran validator yaitu menggunakan KD terbaru yaitu KD 3.4 Menganalisis keterkaitan struktur jaringan tumbuhan dan fungsinya, serta teknologi yang terinspirasi oleh struktur tumbuhan dan 4.4 Menyajikan karya dari hasil penelusuran berbagai sumber informasi tentang teknologi yang terinspirasi dari hasil pengamatan struktur tumbuhan. Menurut validsator langkah dari inkuiri terbimbing ada beberapa yang tidak berurutan sehingga diperbaiki seperti penyajian menguji hipotesis diletakkan lebih dahulu baru kemudian lanjutkan dengan mengumpulkan data. Perbaikan lain sesuai saran validator adalah waktu untuk setiap satu jam pelajaran pada RPP yang semula 45 menit menjadi 40 menit.

Saran perbaikan dari validator pada aspek tampilan dan media adalah memperbaiki tampilan cover, ilustrasi gambar diperjelas, Perbaikan yang dilakukan pada aspek tampilan dan media adalah memperbaiki desain cover, mengganti ilustrasi gambar yang kurang jelas dengan gambar yang lebih jelas, dan memperbaiki penulisan judul.

\section{KESIMPULAN}

Berdasarkan hasil penelitian dan analisis temuan-temuan selama penelitian maka diperoleh kesimpulan bahwa LKPD berbasis keterampilan proses sains model inkuiri terbimbing pada materi struktur dan fungsi jaringan tumbuhan di SMP sangat layak digunakan sebagai perangkat pembelajaran dengan rata-rata persentase skor penilaian validator yaitu $81,48 \%$. LKPD berbasis keterampilan proses sains model inkuiri terbimbng pada materi stuktur dan fungsi jaringan tumbuhan di SMP dapat diterapkan sebagai perangkat pembelajaran berdasarkan nilai rata-rata persentase skor penilaian dari peserta didik yaitu $77,37 \%$.

\section{DAFTAR PUSTAKA}

[1] Anam, R.S. 2014. Analisis Keterampilan Proses Sains Siswa Madrasah Ibtidaiyah di Kabupaten Sumedang. Prosiding Konfrensi Pendidikan Dasar SPS UPI 2014. 5 (2): 274282.

[2] Akbar, S. 2013. Instrumen Perangkat Pembelajaran. Bandung: Remaja Rosdakarya.

[3] Domopoli, I., Yohanita, A.M., Nurhidaya, N., \& Murtijani, M. 2018. Meningkatkan Keterampilan Proses Sains dan Hasil Belajar Siswa Melalui Pembelajaran Berbasis Inkuiri. Jurnal Bioedukatika. 6 (1): 22-30.

[4] Firdaus, M., \& Wilujeng, I. 2018 Pengembangan LKPD Inkuiri Terbimbing untuk Meningkatkan Keterampilan Berpikir Kritis dan Hasil Belajar Peserta Didik. Jurnal Inovasi Pembelajaran IPA. 4 (1): 26-40.

[5] Hanim, F., Dwi, R., \& Fauziyah, S. 2018. Keterampilan Proses Sains Dan Motivasi Terhadap Hasil Belajar IPA Kelas IV SD Negeri 164330 Tebingtinggi. Junral Tematik. 7(1): 107-115.

[6] Hikmah, O. (2005). Kurikulum dan Pembelajaran. Jakarta: PT Bumi Aksara.

[7] Islami, M., Khaeruddin., \& Aziz, A. (2019). Pengaruh Lembar Kerja Peserta Didik (LKPD) Berbasis Inkuiri Terbimbing Terhadap Keterampilan Proses Sains Peserta Didik Kelas XI SMAN 8 Makassar. Jurnal Sains dan Pendidikan Fisika. 15 (2): 39-49.

[8] Novitasari, A., Ilyas, A., \& Amanah, S. N. 2017. Pengaruh Model Pembelajaran Inkuiri Terbimbing Terhadap Keterampilan Proses Sains Peserta Didik Pada Materi Fotosintesis Kelas XII IPA Di SMA Yadika Bandar Lampung. Jurnal Tadris Biologi. 8(1): 91-104.

[9] Rahayu ,A ,H \& Poppy, A (2017). Analisis Profil Keterampilan Proses Sains Siswa Sekolah Dasar Di 
Kabupaten Sumedang. Jurnal Pesona Dasar. 5(2): 22-33.

[10] Said, N. J., Patandean, A. J., \& Rusli, M. A., (2017) Peran Pembelajaran Inkuiri Terbimbing terhadap Keterampilan Proses Sains pada Peserta Dididk Kelas X SMA Negeri 2 Polewali. Jurnal Sains dan Pendidikan Fisika. 13 (3): 225-262.

[11] Sari, D. P., Caswita., \& Bharata, H. (2017). Pengembangan LKPD Berbasis Inkuiri Terbimbing untuk Meningkatkan Keterampilan Berpikir Kritis Siswa. Jurnal Pendidikan Matematika Universitas Lampung. 5 (11): 1-13.

[12] Sugiono. (2016). Metode Penelitian Pendidikan Pendekatan Kuantitatif, Kualitatif, dan $R$ \& D. Bandung: Alfabeta.

[13] Gunawan, G., Harjono, A., \& Kusdiastuti, M. (2019). Perangkat Pembelajaran Model Inkuiri dipadu Advance Organizer (AO) untuk Meningkatkan Penguasaan Konsep dan Kemampuan Pemecahan Masalah Fisika Siswa. Jurnal Pijar Mipa, 14(2), 1-6.
[14] Sukarno., Permasari. A., \& Hamidah. I. 2013. The Profile of Science Process Skills (SPS) Students at Secondary High School (Case Study in Jambi). International Journal of Scientific Engineering and Research (IJSER). 1(1): 2347-3878.

[15] Izzatunnisa, I., Andayani, Y., \& Hakim, A. (2019). Pengembangan LKPD berbasis pembelajaran penemuan untuk meningkatkan kemampuan literasi sains peserta didik pada materi kimia SMA. Jurnal Pijar Mipa, 14(2), 49-54.

[16] Ibrahim, I., Gunawan, G., \& Kosim, K. (2020). Validitas Perangkat Pembelajaran Fisika Berbasis Model Discovery dengan Pendekatan Konflik Kognitif. Jurnal Pijar Mipa, 15(3), 214-218.

[17] Chandrai, M. A., Hakim, A., \& Junaidi, E. (2015). Pengaruh Penerapan Pembelajaran Peta Konsep Terhadap Pemahaman Konsep Koloid Siswa Kelas Xi Sman 2 Mataram Tahun Ajaran 2013/2014. Jurnal Pijar Mipa, 10(1). 